TITLE:

\title{
Metal oxide promoted TiO2 catalysts for photo-assisted selective catalytic reduction of $\mathrm{NO}$ with $\mathrm{NH} 3$
}

\section{AUTHOR(S):}

Yamazoe, Seiji; Masutani, Yasuyuki; Shishido, Tetsuya; Tanaka, Tsunehiro

\section{CITATION:}

Yamazoe, Seiji ...[et al]. Metal oxide promoted TiO2 catalysts for photo-assisted selective catalytic reduction of NO with NH3. Research on Chemical Intermediates 2008, 34(5-7): 487-494

\section{ISSUE DATE:}

2008-05

URL:

http://hdl.handle.net/2433/85339

\section{RIGHT:}

c Koninklijke Brill NV, Leiden, 2008.; この論文は出版社版でありません 。引用の際には出版社版をご確認ご利用ください。; This is not the published version. Please cite only the published version. 
Yamazoe et al Metal oxide promoted $\mathrm{TiO}_{2}$ catalysts for photo-assisted selective catalytic reduction of $\mathrm{NO}$ with $\mathrm{NH}_{3}$ $1 / 15$

\section{Title}

Metal oxide promoted $\mathrm{TiO}_{2}$ catalysts for photo-assisted selective catalytic reduction of $\mathrm{NO}$ with $\mathrm{NH}_{3}$

Seiji Yamazoe, Yasuyuki Masutani, Tetsuya Shishido and Tsunehiro Tanaka*

Department of Molecular Engineering, Graduate school of engineering, Kyoto University, Kyoto 615-8510, Japan

*tanakat@moleng.kyoto-u.ac.jp

\section{Key Words}

$\mathrm{TiO}_{2}$, photocatalyst, SCR, transition metal oxide, $\mathrm{NH}_{3}$, NO 
Yamazoe et al

Metal oxide promoted $\mathrm{TiO}_{2}$ catalysts for photo-assisted selective catalytic reduction of

$\mathrm{NO}$ with $\mathrm{NH}_{3}$

$2 / 15$

\section{Abstract}

The photo-assisted selective catalytic reduction of $\mathrm{NO}$ with $\mathrm{NH}_{3}$ (Photo-SCR) was performed over $\mathrm{TiO}_{2}$ modified by supporting $1 \mathrm{wt} . \%$ various transition metal (V, Cr, Mn, Fe, $\mathrm{Co}, \mathrm{Ni}, \mathrm{Cu}, \mathrm{Zn}, \mathrm{Y}, \mathrm{Zr}, \mathrm{Nb}, \mathrm{Mo}$, Ta or $\mathrm{W}$ ) oxides aiming at the improvement of the photo-SCR activity. The addition of $\mathrm{Nb}$, Mo or $\mathrm{W}$ oxide to $\mathrm{TiO}_{2}$ was found to enhance the photo-SCR activity. We have reported that the amount of acid sites on $\mathrm{TiO}_{2}$ is one of the key factors to the photo-SCR activity. The increase in the activity depends on the enhancement of acidity of catalyst by the addition of Nb, Mo or W oxide. On the contrary, the addition of $\mathrm{V}, \mathrm{Cr}, \mathrm{Mn}, \mathrm{Fe}, \mathrm{Co}, \mathrm{Ni}$ or $\mathrm{Cu}$ oxide to $\mathrm{TiO}_{2}$ lowered the photo-SCR activity although addition of metal cations also change the acidity of $\mathrm{TiO}_{2}$. We guess that the reduction of the activity was caused by two reasons; the first is that the sites newly formed on these transition metal oxides is not photoactive and the second is that $\mathrm{TiO}_{2}$ supporting $\mathrm{V}$, $\mathrm{Cr}, \mathrm{Mn}, \mathrm{Fe}, \mathrm{Co}$, Ni or $\mathrm{Cu}$ oxides had low stabilities under the reaction condition, i.e., the chemical state of the cations changes during the reaction. Therefore, we concluded that the increase in the acid sites which is active sites for photo-SCR and the stability of the catalysts are important for the photo-SCR. 
Yamazoe et al Metal oxide promoted $\mathrm{TiO}_{2}$ catalysts for photo-assisted selective catalytic reduction of $\mathrm{NO}$ with $\mathrm{NH}_{3}$ $3 / 15$

\section{Introduction}

NOx is an air pollutant and causes town smog and acid rain. It is important to remove NOx exhausted in the stationary emission source and mobile emission source. In the stationary emission source, such as a power station, waste incinerator and an industrial boiler, NOx is removed by an efficient technology of selective catalytic reduction (SCR) with $\mathrm{NH}_{3}$ in the presence of $\mathrm{O}_{2}$. Industrial SCR systems are carried out over $\mathrm{V}_{2} \mathrm{O}_{5}-\mathrm{WO}_{3} / \mathrm{TiO}_{2}$ or $\mathrm{V}_{2} \mathrm{O}_{5}-\mathrm{MoO}_{3} / \mathrm{TiO}_{2}$ catalysts at $573-673 \mathrm{~K}^{1-4}$. The SCR process is often located at downstream of the desulfurizer, dehalogenizer and electrostatic precipitators where $\mathrm{SO} x$, halogen compounds and ash are removed because these materials cause the deactivation of catalyst. Since the emission gas temperature in the downstream is below $423 \mathrm{~K}$, it is necessary to develop SCR system operated at low temperature without re-heating the fuel gas ${ }^{5-7}$.

We paid attention to photocatalyst operated at low temperature in order to develop low temperature SCR system. We have already reported that photo-SCR of NO with $\mathrm{NH}_{3}$ in the presence of $\mathrm{O}_{2}$ proceeds at room temperature over Rb-ion-modified vanadium oxide supported on silica $\left(\mathrm{Rb}_{2} \mathrm{O}-\mathrm{V}_{2} \mathrm{O}_{5} / \mathrm{SiO}_{2}\right)^{8}$, titanium oxide supported on silica $\left(\mathrm{TiO}_{2} / \mathrm{SiO}_{2}\right)^{9}$ and titanium dioxide $\left(\mathrm{TiO}_{2}\right)^{10,11}$ under irradiation. When $\mathrm{TiO}_{2}$ is used as a catalyst, $83 \%$ of $\mathrm{NO}$ conversion and $96 \%$ of $\mathrm{N}_{2}$ selectivity can be achieved in the conventional fixed bed flow system at $8,000 \mathrm{~h}^{-112}$. However, this photo-SCR activity is low in comparison with industrial SCR system and it is necessary to increase the photo-SCR activity.

We have reported that the acid sites on $\mathrm{TiO}_{2}$ are active sites for the photo-SCR reaction and the activity depends on the amount of the acid sites ${ }^{10}$. Therefore, it is expected that the enhancement of the acidity of the catalyst improves the activity. The addition of the transition metal oxide to the supports (metal oxides) often generates the 
Yamazoe et al Metal oxide promoted $\mathrm{TiO}_{2}$ catalysts for photo-assisted selective catalytic reduction of $\mathrm{NO}$ with $\mathrm{NH}_{3}$ $4 / 15$

further surface acidity because of an increase in the polarizability in the supports modified with the transition metal oxide ${ }^{13}$. Some researchers reported that the acidity of $\mathrm{TiO}_{2}$ was enhanced and the acid property of $\mathrm{TiO}_{2}$ was changed by the addition of transition metal oxides (W, Mo, V, Fe, Mn, Cr or Cu oxide) ${ }^{6,7,13}$. Recently, some transition metal supporting catalysts, such as $\mathrm{MnO}_{x} / \mathrm{Al}_{2} \mathrm{O}_{3}{ }^{14}, \mathrm{MnO}_{x} / \mathrm{TiO}_{2}{ }^{6}, \mathrm{CuO} / \mathrm{Al}_{2} \mathrm{O}_{3}{ }^{15}$, $\mathrm{CuO} / \mathrm{TiO}_{2}{ }^{16}$ and $\mathrm{Fe}_{2} \mathrm{O}_{3} / \mathrm{TiO}_{2}{ }^{17}$, have showed high activities for the low temperature SCR systems. The high activity in these reaction systems is thought to be due to an increase of active sites, the enhancement of the interaction between catalyst and substrate, and improvement of the stability by supported transition metal. In the present work, we carried out photo-SCR of $\mathrm{NO}$ with $\mathrm{NH}_{3}$ over $\mathrm{TiO}_{2}$ promoted with various transition metal oxides and contributed the development of active catalyst in the photo-SCR. 
Yamazoe et al Metal oxide promoted $\mathrm{TiO}_{2}$ catalysts for photo-assisted selective catalytic reduction of $\mathrm{NO}$ with $\mathrm{NH}_{3}$ $5 / 15$

\section{Experimental}

$\mathrm{TiO}_{2}$ used in this study is Super Titania F-6 (Lot No.H04320) kindly supplied from SHOWA DENKO. This sample was hydrated in distilled water at $353 \mathrm{~K}$ for $2 \mathrm{~h}$ and filtered with suction, followed by dryness at $383 \mathrm{~K}$ over night. Dried sample was calcined in dry air at $673 \mathrm{~K}$ for $3 \mathrm{~h}$. Thus prepared $\mathrm{TiO}_{2}$ exhibited a specific surface area of $76.6 \mathrm{~m}^{2} / \mathrm{g}$ determined by $\mathrm{N}_{2}$ adsorption. The crystal phases of this sample were 91.3\% anatase and $8.7 \%$ rutile determined by SHIMADZU XD-D1 X-ray diffractometer using $\mathrm{Cu} \mathrm{K} \alpha$ radiation. The $\mathrm{TiO}_{2}$ catalysts promoted with various transition metal oxides were prepared by the wet impregnation followed by evaporation to dryness. Super Titania F-6 were impregnated with aqueous solutions of various transition metal precursors (showen in Table 1) at $353 \mathrm{~K}$ and concentrated at $353 \mathrm{~K}$. After these samples were dried at $383 \mathrm{~K}$ over night, these were calcined in dry air at 673 K for $3 \mathrm{~h}$.

Photo-SCR activity measurements were carried out in a conventional fixed bed flow system at room temperature. Catalysts were fixed with quartz wool and filled a quartz reactor which had flat facet $\left(12 \times 10 \times 1 \mathrm{~mm}^{3}\right)$. Before reactions, catalysts were pretreated at $673 \mathrm{~K}$ by flowing $10 \% \mathrm{O}_{2}$ diluted with $\mathrm{Ar}$ at $50 \mathrm{ml} / \mathrm{min}$. The typical reaction gas composition was as follows: $\mathrm{NH}_{3}: 1000 \mathrm{ppm}, \mathrm{NO}: 1000 \mathrm{ppm}, \mathrm{O}_{2}: 2 \%, \mathrm{Ar}$ balance. PERKIN-ELMER PE300BF $300 \mathrm{~W}$ Xe lamp was used as a light source and samples were irradiated from the one side of the flat facets of the reactor with this lamp. $\mathrm{N}_{2}$ and $\mathrm{N}_{2} \mathrm{O}$ products were analyzed by a SHIMADSU GC-8A TCD gas chromatograph with MS-5A column for $\mathrm{N}_{2}$ detection and Chromosorb 103 for $\mathrm{N}_{2} \mathrm{O}$. The photo-SCR was carried out in the low active condition (GHSV $=50,000 \mathrm{~h}^{-1}$ ) in order to that the activity is not saturated. 
Yamazoe et al Metal oxide promoted $\mathrm{TiO}_{2}$ catalysts for photo-assisted selective catalytic reduction of

\section{Result and Discussion}

Table 1 shows the photo-SCR activities of $\mathrm{TiO}_{2}$ and various transition metal oxide promoted $\mathrm{TiO}_{2}$ catalysts. $42.4 \% \mathrm{NO}$ conversion was obtained on pure $\mathrm{TiO}_{2}$ and traced $\mathrm{N}_{2} \mathrm{O}$ was detected over only $\mathrm{TiO}_{2}$ promoted $\mathrm{Nb}$, Mo or $\mathrm{W}$ oxide catalysts. The activities of $\mathrm{Zn}, \mathrm{Y}$, Zr or Ta oxide added to $\mathrm{TiO}_{2}$ samples were nearly equal to the activity of pure $\mathrm{TiO}_{2}$. The addition of $\mathrm{Nb}, \mathrm{W}$ or Mo enhanced the photo-SCR, and it was found that $1 \mathrm{wt} . \% \mathrm{WO}_{3} / \mathrm{TiO}_{2}$ was the most active catalyst (63.6 \% NO conversion) in all samples. On the other hand, $\mathrm{V}, \mathrm{Cr}, \mathrm{Mn}, \mathrm{Fe}, \mathrm{Co}, \mathrm{Ni}$, or $\mathrm{Cu}$ oxide addition to $\mathrm{TiO}_{2}$ catalysts exhibited lower activities than pure $\mathrm{TiO}_{2}$. We have already reported that the active site of photo-SCR is acid site on $\mathrm{TiO}_{2}{ }^{11}$ and acidity of the catalyst is an important factor to determine the photo-SCR activity ${ }^{12}$. It is known that the amount of acid sites on a metal oxide is often increased by addition of other transition metal (V, Cr, Mn, Fe, Co, Ni, Cu, Mo, $W$ et al.) oxides ${ }^{6,13,16}$. It is likely that an increase of active sites enhances the photo-SCR activities. In fact, the addition of $\mathrm{Nb}$, Mo or $\mathrm{W}$ oxide to $\mathrm{TiO}_{2}$ samples enhanced the photo-SCR activity. However, the addition of V, Cr, Mn, Fe, Co, Ni, or Cu oxides exhibited the negative effect for photo-SCR, although these transition oxides adding to $\mathrm{TiO}_{2}$ catalysts might also increase the acidity ${ }^{6,13,16}$. These results suggest that the amount of acid sites is not only the factor in the photo-SCR.

There were several reports that the selective catalytic reduction of $\mathrm{NO}$ with $\mathrm{NH}_{3}$ at 393-623 K was enhanced by using $\mathrm{Mn}, \mathrm{V}$, Fe, $\mathrm{Cu}$ oxide supported on $\mathrm{TiO}_{2}$ catalysts ${ }^{6,14}$, 16-18. In these SCR systems, almost unanimously it is thought that reaction occurs on the transition metal cationic centre (acid site), where both ammonia and NO can be adsorbed ${ }^{4}$. However, $\mathrm{Mn}, \mathrm{V}, \mathrm{Fe}$ and $\mathrm{Cu}$ oxide promoted catalysts showed low activities in the present case, indicating that active sites in the photo-SCR are not the transition metal cationic centre but the acid sites on $\mathrm{TiO}_{2}$. In addition, the activity followed the order $\mathrm{V}>$ $\mathrm{Cr}>\mathrm{Mo} \geq \mathrm{W}$ in low temperature $\mathrm{SCR}^{18}$, while in the present photo-SCR the activity followed the order $\mathrm{W}>\mathrm{Mo}>\mathrm{Cr}>\mathrm{V}$. We speculate that the reason why the activities of 
Yamazoe et al

Metal oxide promoted $\mathrm{TiO}_{2}$ catalysts for photo-assisted selective catalytic reduction of

$\mathrm{NO}$ with $\mathrm{NH}_{3}$

$7 / 15$

$\mathrm{V}, \mathrm{Cr}, \mathrm{Mn}, \mathrm{Fe}, \mathrm{Co}, \mathrm{Ni}$, Cu oxide promoted catalysts were lower than that of pure $\mathrm{TiO}_{2}$ is that the active sites on $\mathrm{TiO}_{2}$ is covered with these transition metal oxides, resulting in the formation of acid sites on themselves.

It is thought that the stability of the catalyst under photo-reaction is important for this reaction. Fig. 1 shows the time courses of the photo-SCR reaction at GHSV $=50,000$ $\mathrm{h}^{-1}$ over pure $\mathrm{TiO}_{2}$, 1 wt. $\% \mathrm{CrO}_{2} / \mathrm{TiO}_{2}$, 1 wt. $\% \mathrm{ZrO}_{2} / \mathrm{TiO}_{2}$ and 1 wt.\% $\mathrm{WO}_{3} / \mathrm{TiO}_{2}$, whose activities were lower, the same and higher catalysts than pure $\mathrm{TiO}_{2}$ respectively for example. In the cases of pure $\mathrm{TiO}_{2}$, $1 \mathrm{wt} . \% \mathrm{ZrO}_{2} / \mathrm{TiO}_{2}$ and $1 \mathrm{wt} . \% \mathrm{WO}_{3} / \mathrm{TiO}_{2}$, the photo-SCR activity reached to the steady state activity for 30-60 min without deactivation and we confirmed that this activity was kept for at least $15 \mathrm{~h}$. Same results were obtained over $\mathrm{Zn}, \mathrm{Y}$, Ta, $\mathrm{Nb}$ or Mo promoted $\mathrm{TiO}_{2}$ catalyst. On the other hand, in the case of 1wt.\% $\mathrm{CrO}_{3} / \mathrm{TiO}_{2}$, the photo-SCR activity decreased as the time going on and after that, the activity reached to the steady state. $\mathrm{V}, \mathrm{Mn}, \mathrm{Fe}, \mathrm{Co}, \mathrm{Ni}$, or $\mathrm{Cu}$ oxide addition to $\mathrm{TiO}_{2}$ catalysts, which showed the lower activities than pure $\mathrm{TiO}_{2}$, exhibited the similar behaviours to Cr oxide supported catalyst. It is thought that this deactivation depends on the low stability of the catalysts under photo-reaction. It was reported that $\mathrm{TiO}_{2}$ supported $\mathrm{Mn}, \mathrm{Cr}$, Co or $\mathrm{Cu}$ oxide catalysts came under the influence of water under the SCR reaction and the activity decreased as the increase in the water concentration ${ }^{7}$. The stoichiometric equation of the photo-SCR is displayed as follows:

$$
4 \mathrm{NO}+4 \mathrm{NH}_{3}+\mathrm{O}_{2} \rightarrow 4 \mathrm{~N}_{2}+6 \mathrm{H}_{2} \mathrm{O}
$$

The produced water in the photo-SCR would affect the photo-SCR activity and make the activity reduced as well as in the cases of the reported SCR systems ${ }^{19}$. Moreover, UV-Vis-NIR spectra of $\mathrm{TiO}_{2}$ supported $\mathrm{Cr}$ or $\mathrm{Cu}$ oxide catalysts revealed that the states of $\mathrm{Cr}$ and $\mathrm{Cu}$ oxides were altered by the photo-SCR reaction. Fig. 2 shows the UV-Vis-NIR spectra of $\mathrm{TiO}_{2}$ supported $\mathrm{Cr}$ or $\mathrm{Cu}$ oxide catalysts before and after reaction. The $\mathrm{TiO}_{2}$ supported Cr oxide before reaction showed three absorption bands centred at 290, 433 and $664 \mathrm{~nm}$. After photo-SCR reaction, the intensities of the absorption bands at 290 and 454 
Yamazoe et al Metal oxide promoted $\mathrm{TiO}_{2}$ catalysts for photo-assisted selective catalytic reduction of $\mathrm{NO}$ with $\mathrm{NH}_{3}$ $8 / 15$ $\mathrm{nm}$ decreased and that of the band at 600-800 nm increased. A $\mathrm{CrO}_{3}$ crystallite consisted from $\mathrm{Cr}^{6+}$ which has tetrahedral structure exhibits two LMCT bands at 280 and $400 \mathrm{~nm}^{20}$. A $\mathrm{Cr}_{2} \mathrm{O}_{3}$ crystallite which has octahedral $\mathrm{Cr}^{3+}$ shows a large d-d transition band in the region of $600-800 \mathrm{~nm}$. The change of UV-Vis-NIR spectrum by the photo-reaction indicates that $\mathrm{Cr}^{6+}$ species on the catalyst was reduced and $\mathrm{Cr}^{3+}$ species was formed. The same alternation was observed at $\mathrm{Cu}$ oxide supported on $\mathrm{TiO}_{2}$ catalyst. The UV-Vis-NIR spectrum before reaction (Fig. 2b) showed that two absorption bands in the region of 250-400 nm and 600-1200 nm. Both a $\mathrm{Cu}(\mathrm{OH})_{2}$ and a $\mathrm{CuAl}_{2} \mathrm{O}_{4}$ crystallites which have octahedral and tetrahedral $\mathrm{Cu}^{2+}$ species respectively exhibit absorption band in the region of $600-1400 \mathrm{~nm}^{21}$. On the other hand, $\mathrm{Cu}_{2} \mathrm{O}$ which has $\mathrm{Cu}^{+}$species show a band gap direct transition around $510 \mathrm{~nm}$. In Fig. 2b, the absorbance at 400-600 nm increased and that at $600-1200 \mathrm{~nm}$ decrease after the photo-SCR reaction. This alternation indicates that $\mathrm{Cu}^{2+}$ species declined and $\mathrm{Cu}^{+}$species was generated under photo-SCR condition. These results indicate that $\mathrm{Cr}$ or $\mathrm{Cu}$ oxide added to $\mathrm{TiO}_{2}$ catalysts are not stable under photo-SCR condition and the reduction of $\mathrm{Cr}^{6+}$ and $\mathrm{Cu}^{2+}$ is one of the deactivation factor. On the other hand, not only $\mathrm{W}$ oxide but also $\mathrm{Mo}$ and $\mathrm{Nb}$ oxide promoted $\mathrm{TiO}_{2}$ catalysts were stable for photo-SCR reaction. It is reported that Mo and W oxides act as both stabilizers and promoter of catalysts ${ }^{4}$. $\mathrm{Nb}$ oxide is reported to promote the catalytic activity as a support for metal oxides ${ }^{22}$. Therefore, the promotion of $\mathrm{Nb}$, Mo and $\mathrm{W}$ oxides to $\mathrm{TiO}_{2}$ may increase the stability of $\mathrm{TiO}_{2}$ and this stability under photo-reaction prevents the activity from the attrition.

Moreover, $\mathrm{W}$ and Mo oxides are known to result in the formation of the acid sites on zirconia or titania ${ }^{13,23}$. We determined the amount of acid sites of the catalyst by $\mathrm{NH}_{3}$ adsorption amount. We confirmed that the amount of acid sites of $\mathrm{TiO}_{2}(0.42 \mathrm{mmol}$ $\left.\mathrm{g}^{-1}\right)$ increased by the addition of $\mathrm{Nb}\left(0.46 \mathrm{mmol} \mathrm{g}^{-1}\right)$, Mo $\left(0.50 \mathrm{mmol} \mathrm{g}{ }^{-1}\right)$ or W $(0.44$ mmol g$~^{-1}$ ) oxide. We have demonstrated that the active site of the photo-SCR is the acid site on the catalyst. This increase of the acidity caused by the promotion of $\mathrm{Nb}$, Mo or $\mathrm{W}$ 
Yamazoe et al

Metal oxide promoted $\mathrm{TiO}_{2}$ catalysts for photo-assisted selective catalytic reduction of

$\mathrm{NO}$ with $\mathrm{NH}_{3}$

oxide to $\mathrm{TiO}_{2}$ made the activity enhanced. We concluded that both the stability and the acidity of the catalyst are important factor for the photo-SCR.

Fig. 3 shows the NO conversion and $\mathrm{N}_{2}$ selectivity as a function of GHSV over 1wt.\% $\mathrm{WO}_{3} / \mathrm{TiO}_{2}$ in the photo-SCR. $1 \mathrm{wt} . \% \mathrm{WO}_{3} / \mathrm{TiO}_{2}$, which showed the highest activity in this study, exhibited $92 \%$ NO conversion and $99 \% \mathrm{~N}_{2}$ selectivity at GHSV = $16,000 \mathrm{~h}^{-1}$. At present, it is necessary of the development of SCR system, which has above $90 \% \mathrm{NO}$ conversion and high $\mathrm{N}_{2}$ selectivity and is operated at $\leq 423 \mathrm{~K}$ at high GHSV value ${ }^{5-7}$. Our photo-SCR system operated at room temperature under UV irradiation fills these demands and is available for the low temperature SCR system. 
Yamazoe et al Metal oxide promoted $\mathrm{TiO}_{2}$ catalysts for photo-assisted selective catalytic reduction of

\section{Conclusion}

We carried out the photo-SCR at room temperature over $\mathrm{TiO}_{2}$ promoted by various transition metal oxides. The addition of $\mathrm{Nb}$, Mo or $\mathrm{W}$ oxides to $\mathrm{TiO}_{2}$ enhanced the photo-SCR activity although the addition of V, Cr, Mn, Fe, Co, Ni, or Cu oxides gave the negative effect to the photo-SCR activity. The promoters of $\mathrm{Nb}$, Mo and $\mathrm{W}$ oxides contribute to the enhancements of the stability and the acidity of catalyst and we concluded that these enhancements led the increase in the photo-SCR activity. Moreover, 1wt.\% $\mathrm{WO}_{3} / \mathrm{TiO}_{2}$ catalyst exhibited $92 \% \mathrm{NO}$ conversion and $99 \% \mathrm{~N}_{2}$ selectivity at GHSV $=16,000 \mathrm{~h}^{-1}$. The catalyst we found in this study would be available at the practical level for the low temperature SCR. 
Yamazoe et al

Metal oxide promoted $\mathrm{TiO}_{2}$ catalysts for photo-assisted selective catalytic reduction of

\section{Reference}

1. H. Bosch, F. Janssen, Catal. Today, 2. 369 (1988).

2. S. CHO, Chem. Eng. Prog., 90. 39 (1994).

3. V. Parvulescu, P. Grange, B. Delmon, Catal. Today, 46. 233 (1998).

4. G. Busca, L. Lietti, G. Ramis, F. Berti, Appl. Catal. B, 18. 1 (1998).

5. R. Long, R. Yang, R. Chang, Chem. Commun., 452 (2002).

6. $\quad$ D. Pena, B. Uphade, P. Smirniotis, J. Catal., 221. 421 (2004).

7. P. G. Smirniotis, D. A. Pena, B. S. Uphade, Angew. Chem. Int. Ed., 40. 2479 (2001).

8. T. Tanaka, K. Teramura, T. Funabiki, Phys. Chem. Chem. Phys., 2. 2681 (2000).

9. T. Tanaka, K. Teramura, T. Yamamoto, S. Takenaka, S. Yoshida, T. Funabiki, J. Photochem. Photobio. A, 148. 277 (2002).

10. T. Tanaka, K. Teramura, K. Arakaki, T. Funabiki, Chem. Commun., 2742 (2002).

11. K. Teramura, T. Tanaka, T. Funabiki, Langmuir, 19. 1209 (2003).

12. S. Yamazoe, T. Okumura, K. Teramura, T. Tanaka, Catal. Today, 111. 266 (2006).

13. J. Papp, S. Soled, K. Dwight, A. Wold, Chem. Mater., 6. 496 (1994).

14. W. Kijlstra, D. Brands, H. Smit, E. Poels, A. Bliek, J. Catal., 171. 219 (1997).

15. G. Centi, S. Perathoner, D. Biglino, E. Giamello, J. Catal., 151. 75 (1995).

16. G. Ramis, L. Yi, G. Busca, M. Turco, E. Kotur, R. J. Willey, J. Catal., 157. 523Y (1995).

17. A. Kato, S. Matsuda, F. Nakajima, M. Imanri, I. Watanabe, J. Phys. Chem., 85. 1710 (1981).

18. K. Bourikas, C. Fountzoula, C. Kordulis, Appl. Catal. B, 52.145 (2004).

19. J. N. Armor, Catal. Today, 26. 147 (1995).

20. $\quad$ F. Amano, T. Yamaguchi, T. Tanaka, J. Phys. Chem.B, 110. 281 (2006).

21. T. Yamamoto, T. Tanaka, R. Kuma, S. Suzuki, F. Amano, Y. Shimooka, Y. Kohno, T. Funabiki, S. Yoshida, Phys. Chem. Chem. Phys., 4. 2449 (2002).

22. K. Chary, K. Lakshmi, P. Rao, K. Rao, M. Papadaki, J. Mol. Catal. A-Chem., 223. 353 (2004).

23. L. Li, Y. Yoshinaga, T. Okuhara, Phys. Chem. Chem. Phys., 4. 6129 (2002). 
Yamazoe et al

Metal oxide promoted $\mathrm{TiO}_{2}$ catalysts for photo-assisted selective catalytic reduction of

$\mathrm{NO}$ with $\mathrm{NH}_{3}$

$12 / 15$

Table 1 Precursors of loading metal oxides and results of photo-SCR of NO with $\mathrm{NH}_{3}$ over various catalysts.

\begin{tabular}{|c|c|c|c|}
\hline Catalysts & Precursors & $\begin{array}{c}\mathrm{NO} \\
\text { conversion / \% }\end{array}$ & $\begin{array}{c}\mathrm{N}_{2} \\
\text { selectivity } \\
/ \%\end{array}$ \\
\hline $\mathrm{TiO}_{2}$ & - & 42.4 & 100 \\
\hline 1wt. $\% \mathrm{~V}_{2} \mathrm{O}_{5} / \mathrm{TiO}_{2}$ & Ammonium Vanadate & 17.7 & 100 \\
\hline 1wt.\% $\mathrm{CrO}_{6} / \mathrm{TiO}_{2}$ & Chromium Nitrate & 34.2 & 100 \\
\hline 1wt. $\% \mathrm{MnO} / \mathrm{TiO}_{2}$ & Manganese Chloride & 12.1 & 100 \\
\hline $1 \mathrm{wt} . \%$ & Iron Nitrate & 29.6 & 100 \\
\hline \multicolumn{4}{|l|}{$\mathrm{Fe}_{2} \mathrm{O}_{3} / \mathrm{TiO}_{2}$} \\
\hline $1 w t . \% \mathrm{CoO} / \mathrm{TiO}_{2}$ & Cobalt Acetate & 21.6 & 100 \\
\hline 1 wt. $\% \mathrm{NiO} / \mathrm{TiO}_{2}$ & Nickel Chloride & 27.0 & 100 \\
\hline 1wt.\% $\mathrm{CuO} / \mathrm{TiO}_{2}$ & Copper Nitrate & 26.1 & 100 \\
\hline $1 \mathrm{wt} . \% \mathrm{ZnO} / \mathrm{TiO}_{2}$ & Zinc Acetate & 46.6 & 100 \\
\hline 1wt. $\% \mathrm{Y}_{2} \mathrm{O}_{3} / \mathrm{TiO}_{2}$ & Yttrium Nitrate & 47.0 & 100 \\
\hline 1wt.\% $\mathrm{ZrO}_{2} / \mathrm{TiO}_{2}$ & Zirconium Nitrate & 41.1 & 100 \\
\hline $1 \mathrm{wt} . \%$ & Ammonium Niobium Oxalate & 58.4 & $>99$ \\
\hline \multicolumn{4}{|l|}{$\mathrm{Nb}_{2} \mathrm{O}_{5} / \mathrm{TiO}_{2}$} \\
\hline $1 w t . \%$ & Hexa-Ammonium & 60.2 & $>99$ \\
\hline $\mathrm{MoO}_{3} / \mathrm{TiO}_{2}$ & Heptamolybdate & & \\
\hline $1 w t . \%$ & Tantalum Chloride & 38.6 & 100 \\
\hline \multicolumn{4}{|l|}{$\mathrm{Ta}_{2} \mathrm{O}_{3} / \mathrm{TiO}_{2}$} \\
\hline 1wt.\% $\mathrm{WO}_{3} / \mathrm{TiO}_{2}$ & Ammonium Tangstate & 63.6 & $>99$ \\
\hline
\end{tabular}

Reaction condition; NO: 1000ppm, $\mathrm{NH}_{3}$ : 1000ppm, $\mathrm{O}_{2}$ : 2\%, Ar balance, GHSV: 50,000 h${ }^{-1}$. 


\section{Yamazoe et al} Metal oxide promoted $\mathrm{TiO}_{2}$ catalysts for photo-assisted selective catalytic reduction of
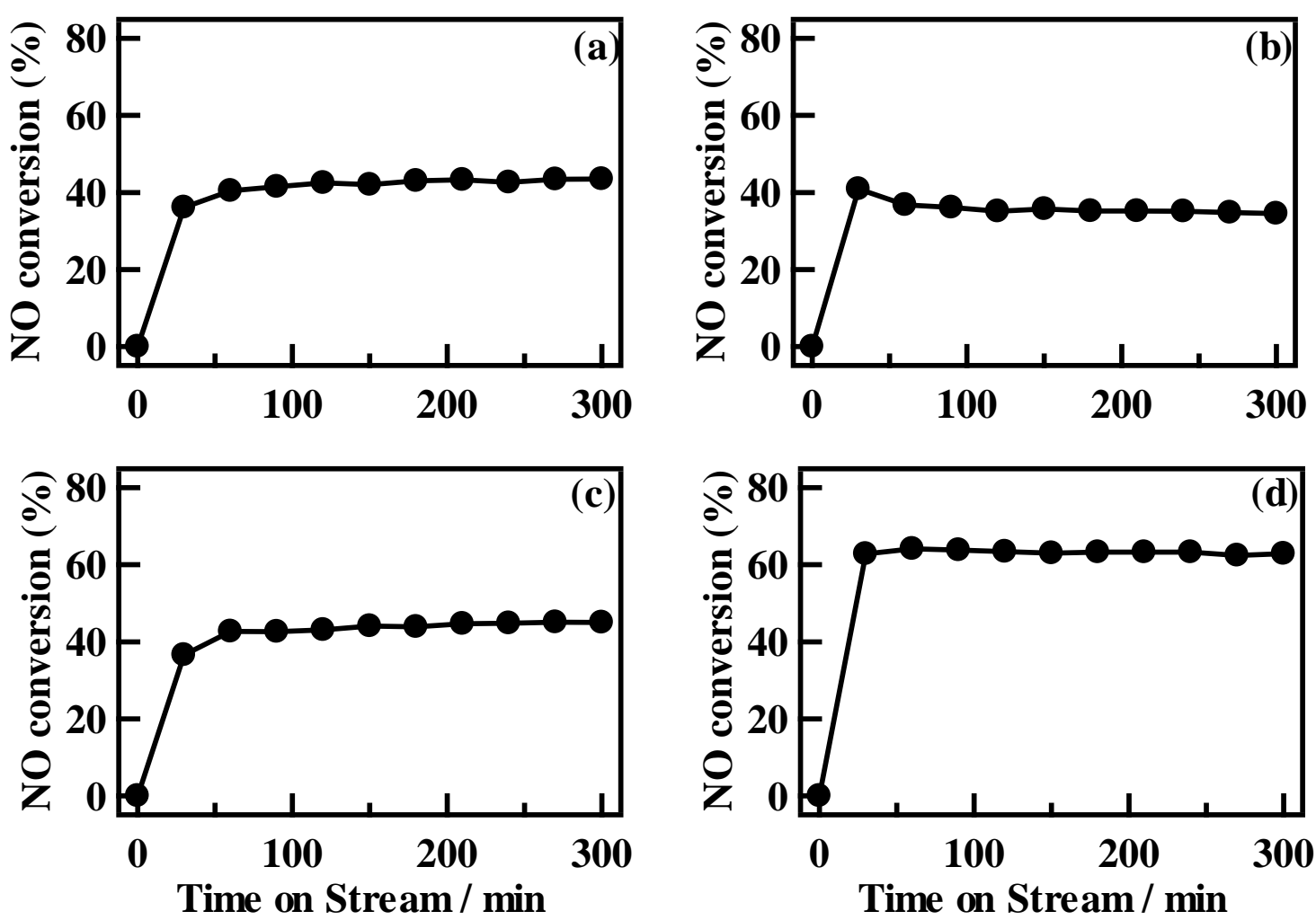

Fig. 1 Time courses of the photo-SCR reactions over (a) $\mathrm{TiO}_{2}$, (b) $1 \mathrm{wt} . \% \mathrm{CrO}_{3} / \mathrm{TiO}_{2}$, (c) 1 wt. $\% \mathrm{ZrO}_{2} / \mathrm{TiO}_{2}$ and (d) $1 \mathrm{wt} . \% \mathrm{WO}_{3} / \mathrm{TiO}_{2}$ at $\mathrm{GHSV}=50,000 \mathrm{~h}^{-1}$. Reaction condition; NO: 1000ppm, $\mathrm{NH}_{3}$ : 1000ppm, $\mathrm{O}_{2}$ : 2\%, Ar balance. 
Yamazoe et al Metal oxide promoted $\mathrm{TiO}_{2}$ catalysts for photo-assisted selective catalytic reduction of $\mathrm{NO}$ with $\mathrm{NH}_{3}$ $14 / 15$
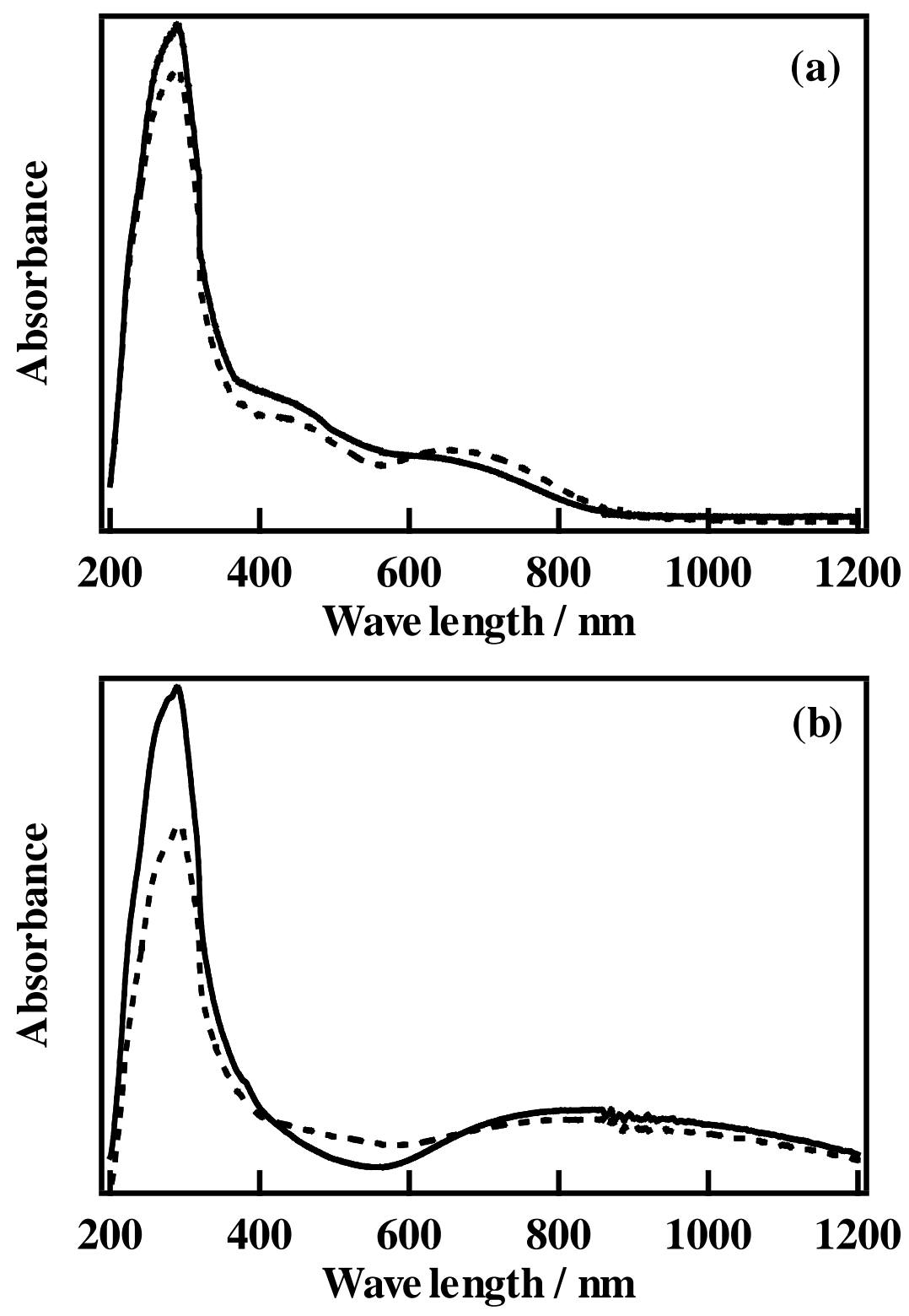

Fig. 2 UV-Vis-NIR spectra of (a) 1 wt. $\% \mathrm{CrO}_{3} / \mathrm{TiO}_{2}$ and (b) 1 wt.\%CuO/TiO 2 before (solid line) and after (broken line) reaction. 
Yamazoe et al Metal oxide promoted $\mathrm{TiO}_{2}$ catalysts for photo-assisted selective catalytic reduction of $\mathrm{NO}$ with $\mathrm{NH}_{3}$ $15 / 15$

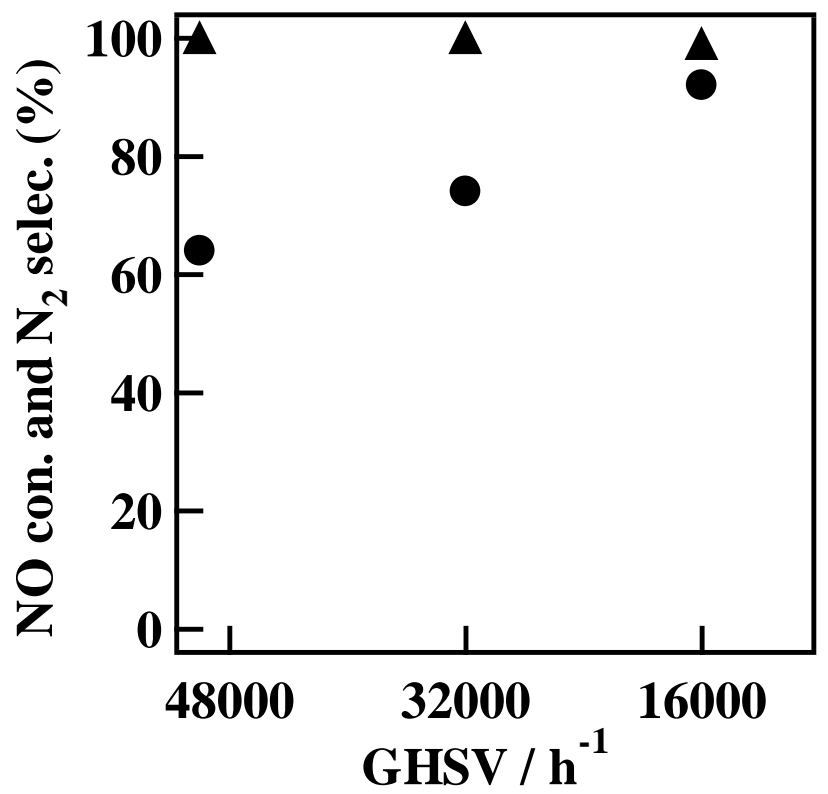

Fig. 3 NO conversion and $\mathrm{N}_{2}$ selectivity at some GHSV over $1 \mathrm{wt} . \% \mathrm{WO}_{3} / \mathrm{TiO}_{2}$. Reaction condition; NO: 1000ppm, $\mathrm{NH}_{3}$ : 1000ppm, $\mathrm{O}_{2}: 2 \%$, Ar balanee. NO conversion, $\boldsymbol{\Delta}: \mathrm{N}_{2}$ selectivity. 